\title{
The 100 Most Influential Publications in Cervical Spine Research
}

Nicola Rüegsegger, ${ }^{*}$ Sufian S. Ahmad, MD ${ }^{*}$ Lorin M. Benneker, MD, ${ }^{*}$ Ulrich Berlemann, MD, ${ }^{\dagger}$ Marius J. B. Keel, MD, ${ }^{*}$ and Sven Hoppe, $\mathrm{MD}^{*}$

\begin{abstract}
Study Design. Bibliometric study of current literature. Objective. To identify and analyze the 100 most cited publications in cervical spine research.

Summary of Background Data. The cervical spine is a dynamic field of research with many advances made within the last century. The literature has, however, never been comprehensively analyzed to identify and compare the most influential articles as measured by the number of citations.

Methods. All databases of the Thomson Reuters Web of Knowledge were utilized in a two-step approach. First, the 150 most cited cervical spine studies up to and including 2014 were identified using four keywords. Second, all keywords related to the cervical spine found in the 150 studies $(n=38)$ were used to conduct a second search of the database. The top 100 most cited articles were hereby selected for further analysis of current and past citations, authorship, geographic origin, article type, and level of evidence.
\end{abstract}

Results. Total citations for the 100 studies identified ranged from 173 to 879 . They were published in the time frame 1952 to 2008 in a total of 30 different journals. Most studies $(n=42)$ were published in the decade 1991-2000. Level of evidence ranged from 1 to 5 with 39 studies in the level 4 category. A total of 13 researchers were first author more than once and nine researchers senior author more than once. The two-step approach with a secondary widening of search terms yielded an additional 27 studies, including the first ranking article.

Conclusion. This bibliometric study is likely to include some of the most important milestones in the field of cervical spine research of the last 100 years.

From the *Department of Orthopedic Surgery and Traumatology, Inselspital, University of Bern, Bern, Switzerland; and 'Das Rückenzentrum, Spine Surgery, Thun, Switzerland.

Acknowledgment date: August 6, 2015. First revision date: September 10, 2015. Acceptance date: September 11, 2015.

The manuscript submitted does not contain information about medical device(s)/drug(s).

No funds were received in support of this work.

No relevant financial activities outside the submitted work.

Address correspondence and reprint requests to Sven Hoppe, MD, Department of Orthopedic Surgery and Traumatology, Inselspital, University of Bern, Freiburgstrasse, 3010 Bern, Switzerland; E-mail: svenhoppe@gmail.com

DOI: 10.1097/BRS.0000000000001261
Key words: bibliometric study, cervical research, cervical spine, citation analysis, citation classics, orthopedic surgery, spine, surgery, top 100 .

Level of Evidence: 3

Spine 2016;41:538-548

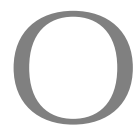

riginally described as a mean to evaluate scientific journals, ${ }^{1}$ citation analysis has become an established tool to measure the impact of scientific articles in bibliometric studies-a subset of systematic reviews. It is based on the idea that publications with a high value to the field of study get cited more often than others. Owing to the vast growth of the scientific literature, an overview of the most relevant past publications has become more important than ever. In more recent years, bibliometric studies have therefore gained momentum and were subsequently published for fields as broad as surgery in general, ${ }^{2}$ medical specialties, ${ }^{3,4}$ anatomic regions, ${ }^{5}$ surgical procedures, ${ }^{6}$ geographic origin of studies, ${ }^{7,8}$ and individual disease entities. ${ }^{9}$

In the field of the human spine, two bibliometric studies have been published. ${ }^{10,11}$ Even though the cervical portion of the spine exhibits some unique anatomic and clinical features, so far there has not been a systematic analysis of the scientific literature about cervical spine research. This study aims to close this gap and give the reader an overview over the most cited cervical spine articles of the last hundred years.

\section{MATERIALS AND METHODS}

\section{Objective}

To identify and analyze the 100 most cited cervical spine research papers published between 1900 and 2014 in any journal (medical and nonmedical).

\section{Inclusion Criteria}

In order to get considered for the top 100 list, a study had to focus on the anatomic region between the skull base and the first thoracic vertebra, and include the bony, cartilaginous, and/or ligamentous structures. If other parts of the body were also under investigation in the same study to the same or a higher degree, the study was excluded. Also, a study was 


\section{Step 1: Keyword Extraction}

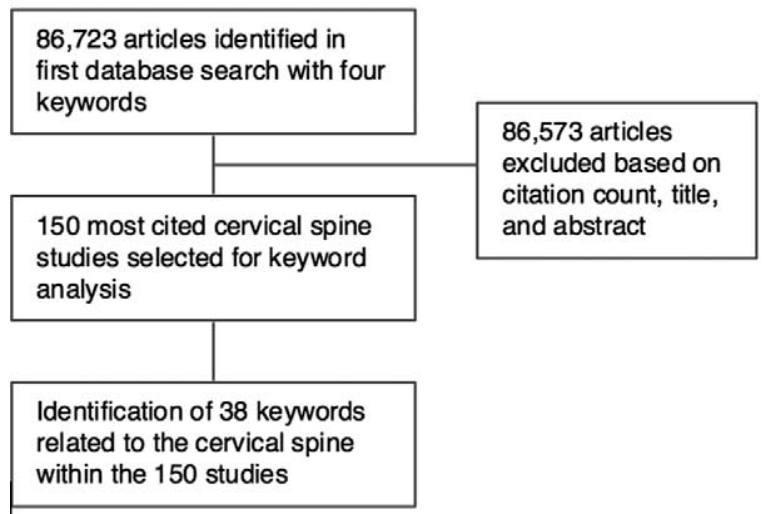

Figure 1. Two-step approach.

not included if it focused on an anatomic structure unrelated to the cervical spine. For example, a study about spontaneous ruptures of the cervical portion of the vertebral artery would not be included while a study about whiplash injury would.

\section{Material}

All databases and all journals of the Thomson Reuter's Web of Knowledge were used to identify eligible studies.

\section{Data Collection}

In order to yield a high comprehensiveness, a two-step approach was chosen, as depicted in the flowchart below (Figure 1).

1. A topic search with the following Boolean query was conducted within the Web of Knowledge databases, the asterisk $\left({ }^{*}\right)$ indicating every possible ending of the corresponding word: (spine OR vertebra*) AND (cervic* OR neck).

This search yielded 86,723 results, which were then sorted in descending order with respect to the number of total citations. Within the first 632 studies, 150 cervical spine papers were identified based on title and abstract.

2. A list of keywords was created with the goal to foresee research titles involving the cervical spine. The previously identified 150 studies were systematically analyzed for possible keywords. Together with additional keywords known to be relevant to the field of cervical spine research (e.g. Klippel-Feil syndrome), a search query consisting of 38 terms was built (Table 1) and used for a second database search by title. This time, every word was delimited by an OR term, hereby further increasing the search results.

The second search yielded 5,584,189 results, which were again sorted in descending order with respect to the number of total citations. Out of the 9694 first studies, 100 cervical spine studies were included based on title and abstract.

For every study included, the following information was extracted: Title, year of publication, first author, senior author, geographic origin, total citations, and citations 2014.

\section{Step 2: Publication Selection}

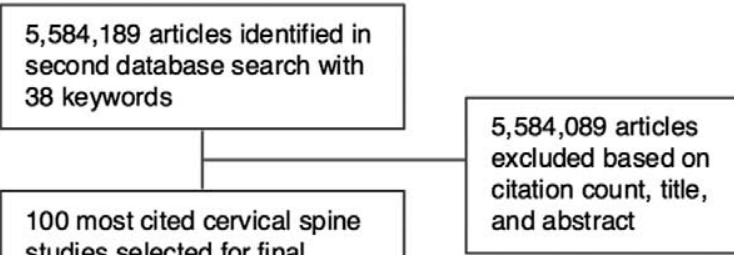

studies selected for final

analysis

\section{Analysis}

Every study was assigned to a subspecialty, type of paper, type of study, and a level of evidence. For the level of evidence classification, the guidelines by J Bone Joint Surg $A m$ were used to assign a number 1 (highest level of evidence) to 5 (lowest level of evidence) for every clinical study. Nonclinical (i.e. basic research) studies were not assigned to a level of evidence. A consensus approach

\section{TABLE 1. Keywords Used in Second Search}

\begin{tabular}{|l|}
\hline Alar Ligament \\
\hline Articular Process \\
\hline Atla* \\
\hline Axi \\
\hline C-Spine \\
\hline C1-C7 (7) \\
\hline Cervic \\
\hline Craniocervic \\
\hline Dens \\
\hline Disc \\
\hline Disk \\
\hline Facet Joint \\
\hline Hangman* \\
\hline Jefferson* \\
\hline Klippel Feil \\
\hline Laminoplast \\
\hline Longitudinal Ligament \\
\hline Myelopath* \\
\hline Neck \\
\hline Occipitocervic* \\
\hline Odontoid \\
\hline Pedic* \\
\hline Radiculopath* \\
\hline Spin* \\
\hline Spondyl* \\
\hline Tetraplegia \\
\hline Transpedic* \\
\hline Transverse Process \\
\hline Uncinate Process \\
\hline Vertebr* \\
\hline Whiplash \\
\hline Zygapophys* \\
\hline
\end{tabular}


was used in cases of disagreement between the researchers. ${ }^{12}$ If a study had only one author, he or she was considered to be both, first and senior author.

The programming language Python (version 3.4.3) was used for the statistical analysis. All studies were ranked for their total number of citations. In cases ties between papers, a second and third degree ordering was performed for average citations per year and the number of citations in 2014, respectively.

Self-citations were not removed or analyzed. In the majority of cases, the error margin introduced by removing self-citations would have been larger than the error margin present by including self-citations.

\section{RESULTS}

The 100 studies included ranged from 879 to 173 citations and were published in a total of 30 different journals (Table 2). The top two journals (Spine and J Bone Joint Surg Am) accounted for 42 studies (Table 3). All studies fell within the time frame from 1952 to 2008 . No studies from the first half of the $20^{\text {th }}$ century were included even though all studies published between 1900 and 2014 were eligible for inclusion. The 1990s were the most active decade with 42 papers represented (Figure 2). There appears to be an inverse correlation between the average citations per year since publication and article age (Figure 3). A total of 14 different countries were identified as country of origin, with the USA in first position $(n=48)$. Nine studies were published from the UK, seven from Canada, followed by Australia and the Netherland $(\mathrm{n}=6)$, Japan and Norway $(\mathrm{n}=5)$, Switzerland $(\mathrm{n}=4)$, Germany $(\mathrm{n}=3)$, Finland and India $(\mathrm{n}=2)$ as well as China, Israel, and New Zealand with one publication each. Even though no language restrictions were imposed during the search process, all 100 studies were published in English. A total of 88 of the included studies were clinical, whereas the remaining 12 were basic research. The evidence level ranged from 1 to 5 with 4 being the most common $(n=43)$ (Figure 4). Average level of evidence per decade changed over time with a trend towards better evidence levels (Figure 2).

There were 13 authors with two first authorships. No authors were first author more than twice. Nine authors were identified as senior authors more than once, ranging from two to five articles each (Table 4).

Most articles were assigned to the subspecialty "degenerative", $(\mathrm{n}=41)$, followed by "trauma" $(\mathrm{n}=28)$, "general cspine" $(\mathrm{n}=10)$, "rheumatology" $(\mathrm{n}=3)$, and "oncology" $(\mathrm{n}=1)$. A total of 17 studies addressed more than one subspecialty ("Various") out of which most $(n=15)$ were assigned to the "surgical technique" type of paper. The latter was also the most common type of paper with 30 studies overall being assigned to "surgical technique", followed by "clinical outcomes" with 11 papers (Table 5). Similarly, the majority of publications were either considered to be "therapeutic" $(\mathrm{n}=44)$ or "prognostic" $(\mathrm{n}=29)$ (Figure 5).

Out of the 100 publications, 73 were identified through the first four keywords search, 27 through the second 38 keywords query. During the first search, the 150 studies included fell within the 632 top ranked studies of the entire search result, leading to a hit-rate of 0.24 . The second search with 38 keywords yielded a hit-rate of 0.01 (100 studies selected out of the 9694 most cited studies in the search results).

The 2012 published citation analysis of the top 100 spine studies by Murray et al listed 14 cervical spine papers. ${ }^{10}$ They all also appear in this study.

\section{DISCUSSION}

Out of the top three publications, two were published in 1958 and both described the anterior removal of cervical intervertebral discs-the $1^{\text {st }}$ ranking one was published by Cloward and the $3^{\text {rd }}$ placed by Smith and Robinson. Despite their age, both studies are still "highly active" with 31 and 46 citations in 2014, respectively (average citations in 2014 for all studies listed: 15 ). This demonstrates the long lasting impact the described surgical technique has had on the field of cervical spine surgery.

Second placed is the publication by Vernon and Mior from 1991 describing the Neck Disability Index, which modifies the Oswestry Low Back Pain Index for its use for the cervical spine. Interestingly, in a recently published bibliographic study of the lumbar spine, a review of the Oswestry Low Back Pain Index published in 2000 is the third most cited lumbar spine paper. ${ }^{11,13}$ This highlights the importance pain and disability classifications play in clinical practice, both for the lumbar and the cervical spine. The Neck Disability Index paper happened to be the most cited study in 2014, too. It was cited 88 times in 2014, more often than the first and third placed papers combined (77 citations). It is therefore possible, that in upcoming years, this paper might become the new number one in cervical spine research in terms of citations.

The most recent publication appearing on the top 100 list is the 2008 paper by Hogg-Johnson et al reviewing the published evidence on the burden of neck pain in the general population. It has an above average citation count in 2014 of 32 citations, indicating a possible further rise in rank in the near future. Furthermore, it has the highest average citation rate between the date of publication and 2013 with 88 citations per year (average: 12.4). This finding illustrates the inverse correlation between average citations per year since publication and article age (Figure 3). In other words: The more recent a publication is, the more often it has gotten cited per year since publication. This is, however, not surprising, since for a more recent study to accumulate enough citations to "keep up" with older publications, it must have had more citations per year since publication. And since this study only lists the most cited papers it was to be expected to see such a phenomenon for younger publications. The oldest paper was published in 1952 by Brain et al and described the neurological manifestations of cervical spondylosis. In 2014, it was cited only five times, thus possibly reflecting a phenomenon known as "obliteration by incorporation": The tendency of classic papers getting cited 


\begin{tabular}{|c|c|c|c|c|}
\hline Rank & Paper & $\begin{array}{l}\text { Total } \\
\text { Citations }\end{array}$ & $\begin{array}{l}\text { Citations/ } \\
\text { Year: Publi- } \\
\text { cation Until } \\
\quad 2013\end{array}$ & $\begin{array}{l}\text { Citations } \\
2014\end{array}$ \\
\hline 1 & $\begin{array}{l}\text { Cloward RB. The anterior approach for removal of ruptured cervical disks. } \\
\text { Journal of neurosurgery } 1958 ; 15: 602-17 \text {. }\end{array}$ & 879 & 15.42 & 31 \\
\hline 2 & $\begin{array}{l}\text { Vernon H, Mior S. The neck disability index-a study of reliability and } \\
\text { validity. Journal of Manipulative and Physiological Therapeutics } \\
\text { 1991;14:409-15 }\end{array}$ & 877 & 35.86 & 88 \\
\hline 3 & $\begin{array}{l}\text { Smith GW, Robinson RA. The treatment of certain cervical-spine disorders by } \\
\text { anterior removal of the intervertebral disc and interbody fusion. The } \\
\text { Journal of bone and joint surgery. American volume 1958;40-A:607-24. }\end{array}$ & 631 & 10.64 & 46 \\
\hline 4 & $\begin{array}{l}\text { Anderson LD, Dalonzo RT. Fractures of odontoid process of axis. Journal of } \\
\text { Bone and Joint Surgery-American Volume 1974;A 56:1663-74. }\end{array}$ & 511 & 12.38 & 28 \\
\hline 5 & $\begin{array}{l}\text { Hilibrand AS, Carlson GD, Palumbo MA, et al. Radiculopathy and } \\
\text { myelopathy at segments adjacent to the site of a previous anterior cervical } \\
\text { arthrodesis. Journal of Bone and Joint Surgery-American Volume } \\
\text { 1999;81A:519-28. }\end{array}$ & 509 & 32.57 & 53 \\
\hline 6 & $\begin{array}{l}\text { Spitzer WO, Skovron ML, Salmi LR, et al. Scientific monograph of the } \\
\text { Quebec task-force on whiplash-associated disorders—redefining whiplash } \\
\text { and its management. Spine 1995;20:S1-S73. }\end{array}$ & 499 & 26.06 & 30 \\
\hline 7 & $\begin{array}{l}\text { Harms J, Melcher RP. Posterior C1-C2 fusion with polyaxial screw and rod } \\
\text { fixation. Spine 2001;26:2467-71. }\end{array}$ & 462 & 34.00 & 54 \\
\hline 8 & $\begin{array}{l}\text { Hoffman JR, Mower WR, Wolfson AB, et al. Validity of a set of clinical } \\
\text { criteria to rule out injury to the cervical spine in patients with blunt } \\
\text { trauma. New England Journal of Medicine 2000;343:94-9. }\end{array}$ & 413 & 28.77 & 39 \\
\hline 9 & $\begin{array}{l}\text { Brooks AL, Jenkins EB. Atlanto-axial arthrodesis by wedge compression method. } \\
\text { Journal of Bone and Joint Surgery-American Volume 1978;60:279-84. }\end{array}$ & 403 & 10.94 & 20 \\
\hline 10 & $\begin{array}{l}\text { Cote P, Cassidy JD, Carroll L. The Saskatchewan Health and Back Pain } \\
\text { Survey-The prevalence of neck pain and related disability in } \\
\text { Saskatchewan adults. Spine 1998;23:1689-98. } \\
\end{array}$ & 386 & 24.53 & 18 \\
\hline 11 & $\begin{array}{l}\text { Bohlman HH. Acute fractures and dislocations of the cervical-spine-analysis } \\
\text { of } 300 \text { hospitalized-patients and review of the literature. Journal of Bone } \\
\text { and Joint Surgery-American Volume 1979;61:1119-42. }\end{array}$ & 376 & 10.71 & 12 \\
\hline 12 & $\begin{array}{l}\text { Nurick S. Pathogenesis of spinal-cord disorder associated with cervical } \\
\text { spondylosis. Brain 1972;95:87-\&. }\end{array}$ & 376 & 8.63 & 22 \\
\hline 13 & $\begin{array}{l}\text { Boden SD, McCowin PR, Davis DO, et al. Abnormal magnetic-resonance } \\
\text { scans of the cervical-spine in asymptomatic subjects-a prospective } \\
\text { investigation. Journal of Bone and Joint Surgery-American Volume } \\
\text { 1990;72A:1178-84. }\end{array}$ & 370 & 15.17 & 21 \\
\hline 14 & $\begin{array}{l}\text { Bohlman HH, Emery SE, Goodfellow DB, et al. Robinson anterior cervical } \\
\text { diskectomy and arthrodesis for cervical radiculopathy-long-term follow- } \\
\text { up of } 100 \text { and } 22 \text { patients. Journal of Bone and Joint Surgery-American } \\
\text { Volume } 1993 ; 75 \mathrm{~A}: 1298-307 .\end{array}$ & 359 & 16.70 & 25 \\
\hline 15 & $\begin{array}{l}\text { Hirabayashi K, Miyakawa J, Satomi K, et al. Operative results and } \\
\text { postoperative progression of ossification among patients with ossification of } \\
\text { cervical posterior longitudinal ligament. Spine } 1981 ; 6: 354-64 \text {. }\end{array}$ & 358 & 9.94 & 40 \\
\hline 16 & $\begin{array}{l}\text { Cassidy JD, Carroll LJ, Cote P, et al. Effect of eliminating compensation for } \\
\text { pain and suffering on the outcome of insurance claims for whiplash injury. } \\
\text { New England Journal of Medicine 2000;342:1179-86. }\end{array}$ & 356 & 26.54 & 11 \\
\hline 17 & $\begin{array}{l}\text { Silber JS, Anderson DG, Daffner SD, et al. Donor site morbidity after anterior } \\
\text { iliac crest bone harvest for single-level anterior cervical discectomy and } \\
\text { fusion. Spine 2003;28:134-9. }\end{array}$ & 349 & 31.20 & 37 \\
\hline 18 & $\begin{array}{l}\text { Stiell IG, Wells GA, Vandemheen KL, et al. The Canadian C-spine rule for } \\
\text { radiography in alert and stable trauma patients. Jama-Journal of the } \\
\text { American Medical Association 2001;286:1841-8. }\end{array}$ & 339 & 25.42 & 34 \\
\hline 19 & $\begin{array}{l}\text { Lord SM, Barnsley L, Wallis BJ, et al. Percutaneous radio-frequency } \\
\text { neurotomy for chronic cervical zygapophyseal-joint pain. New England } \\
\text { Journal of Medicine 1996;335:1721-6. }\end{array}$ & 328 & 17.94 & 23 \\
\hline 20 & $\begin{array}{l}\text { Ranawat CS, Oleary P, Pellicci P, et al. Cervical-spine fusion in rheumatoid- } \\
\text { arthritis. Journal of Bone and Joint Surgery-American Volume 1979;61:1003-10. }\end{array}$ & 323 & 9.21 & 10 \\
\hline
\end{tabular}




\section{TABLE 2 (Continued)}

\begin{tabular}{|c|c|c|c|c|}
\hline Rank & Paper & $\begin{array}{l}\text { Total } \\
\text { Citations }\end{array}$ & $\begin{array}{l}\text { Citations/ } \\
\text { Year: Publi- } \\
\text { cation Until } \\
2013\end{array}$ & $\begin{array}{l}\text { Citations } \\
2014\end{array}$ \\
\hline 21 & $\begin{array}{l}\text { Bovim G, Schrader H, Sand T. Neck pain in the general-population. Spine } \\
\text { 1994;19:1307-9. }\end{array}$ & 320 & 16.21 & 12 \\
\hline 22 & $\begin{array}{l}\text { Kessel M, Balling R, Gruss P. Variations of cervical-vertebrae after expression } \\
\text { of a hox-1.1 transgene in mice. Cell } 1990 ; 61: 301-8 .\end{array}$ & 313 & 13.57 & 1 \\
\hline 23 & $\begin{array}{l}\text { Bailey RW, Badgley CE. Stabilization of the cervical spine by anterior fusion. } \\
\text { The Journal of bone and joint surgery. American volume 1960;42-A:565-94. }\end{array}$ & 312 & 5.60 & 15 \\
\hline 24 & $\begin{array}{l}\text { Goel A, Laheri V. Plate and screw fixation for atlantoaxial subluxation. Acta } \\
\text { Neurochirurgica 1994;129:47-53. }\end{array}$ & 291 & 13.58 & 33 \\
\hline 25 & $\begin{array}{l}\text { Fielding JW, Hawkins RJ. Atlanto-axial rotatory fixation- (fixed rotatory } \\
\text { subluxation of atlanto-axial joint). Journal of Bone and Joint Surgery- } \\
\text { American Volume 1977;59:37-44. }\end{array}$ & 282 & 7.53 & 11 \\
\hline 26 & $\begin{array}{l}\text { Makela M, Heliovaara M, Sievers K, et al. Prevalence, determinants, and } \\
\text { consequences of chronic neck pain in Finland. American Journal of } \\
\text { Epidemiology } 1991 ; 134: 1356-67 \text {. }\end{array}$ & 280 & 12.36 & 8 \\
\hline 27 & Barnsley L, Lord S, Bogduk N. Whiplash injury. Pain 1994;58:283-307. & 277 & 14.26 & 6 \\
\hline 28 & $\begin{array}{l}\text { Madawi AA, Casey ATH, Solanki GA, et al. Radiological and anatomical } \\
\text { evaluation of the atlantoaxial transarticular screw fixation technique. } \\
\text { Journal of Neurosurgery 1997;86:961-8. }\end{array}$ & 274 & 16.06 & 17 \\
\hline 29 & $\begin{array}{l}\text { Hirabayashi K, Watanabe K, Wakano K, et al. Expansive open-door } \\
\quad \text { laminoplasty for cervical spinal stenotic myelopathy. Spine 1983;8:693-9. }\end{array}$ & 272 & 8.43 & 19 \\
\hline 30 & $\begin{array}{l}\text { Payne EE, Spillane JD. The cervical spine-an anatomico-pathological study } \\
\text { of } 70 \text { specimens (using a special technique) with particular reference to the } \\
\text { problem of cervical spondylosis. Brain } 1957 ; 80: 571-\& \text {. }\end{array}$ & 264 & 4.64 & 4 \\
\hline 31 & $\begin{array}{l}\text { Ramirezsolis } \mathrm{R} \text {, Zheng } \mathrm{H} \text {, Whiting J, et al. Hoxb-4 (Hox-2.6) mutant mice } \\
\text { show homeotic transformation of a cervical vertebra and defects in the } \\
\text { closure of the sternal rudiments. Cell 1993;73:279-94. }\end{array}$ & 263 & 13.00 & 3 \\
\hline 32 & $\begin{array}{l}\text { Robinson RA, Walker AE, Donald CF, et al. The results of anterior interbody } \\
\text { fusion of the cervical spine. Journal of Bone and Joint Surgery-American } \\
\text { Volume } 1962 ; 44(8): 1569-1587 \text {. }\end{array}$ & 259 & 5.00 & 4 \\
\hline 33 & $\begin{array}{l}\text { Shields LBE, Raque GH, Glassman SD, et al. Adverse effects associated with } \\
\text { high-dose recombinant human bone morphogenetic protein-2 use in } \\
\text { anterior cervical spine fusion. Spine } 2006 ; 31: 542-7 \text {. }\end{array}$ & 258 & 30.14 & 47 \\
\hline 34 & $\begin{array}{l}\text { Schrader H, Obelieniene D, Bovim G, et al. Natural evolution of late whiplash } \\
\text { syndrome outside the medicolegal context. Lancet 1996;347:1207-11. }\end{array}$ & 253 & 14.71 & 3 \\
\hline 35 & $\begin{array}{l}\text { Allen BL, Ferguson RL, Lehmann TR, et al. A mechanistic classification of } \\
\text { closed, indirect fractures and dislocations of the lower cervical-spine. } \\
\text { Spine } 1982 ; 7: 1-27 \text {. }\end{array}$ & 249 & 7.45 & 18 \\
\hline 36 & $\begin{array}{l}\text { Odom GL, Finney W, Woodhall B. Cervical disk lesions. Journal of the } \\
\text { American Medical Association 1958;166:23-8. }\end{array}$ & 248 & 4.24 & 15 \\
\hline 37 & $\begin{array}{l}\text { Schneider RC, Cherry G, Pantek H. The syndrome of acute central cervical } \\
\text { spinal cord injury; with special reference to the mechanisms involved in } \\
\text { hyperextension injuries of cervical spine. Journal of neurosurgery } \\
1954 ; 11: 546-77 \text {. }\end{array}$ & 247 & 4.10 & 5 \\
\hline 38 & $\begin{array}{l}\text { Brain WR, Northfield D, Wilkinson M. The neurological manifestations of } \\
\text { cervical spondylosis. Brain 1952;75:187-225. }\end{array}$ & 246 & 3.95 & 5 \\
\hline 39 & $\begin{array}{l}\text { Barnsley L, Lord SM, Wallis BJ, et al. The prevalence of chronic cervical } \\
\text { zygapophysial joint pain after whiplash. Spine 1995;20:20-5. }\end{array}$ & 245 & 13.33 & 5 \\
\hline 40 & $\begin{array}{l}\text { Gore DR, Sepic SB. Anterior cervical fusion for degenerated or protruded } \\
\text { disks-a review of } 146 \text { patients. Spine 1984;9:667-71. }\end{array}$ & 244 & 7.97 & 13 \\
\hline 41 & $\begin{array}{l}\text { Eck JC, Humphreys SC, Lim TH, et al. Biomechanical study on the effect of } \\
\text { cervical spine fusion on adjacent-level intradiscal pressure and segmental } \\
\text { motion. Spine } 2002 ; 27: 2431-4 \text {. }\end{array}$ & 240 & 18.73 & 34 \\
\hline 42 & $\begin{array}{l}\text { Lord SM, Barnsley L, Wallis BJ, et al. Chronic cervical zygapophysial joint } \\
\text { pain after whiplash-A placebo-controlled prevalence study. Spine } \\
\text { 1996;21:1737-44. }\end{array}$ & 240 & 13.71 & 7 \\
\hline 43 & $\begin{array}{l}\text { Sen CN, Sekhar LN. An extreme lateral approach to intradural lesions of the } \\
\text { cervical-spine and foramen magnum. Neurosurgery 1990;27:197-204. }\end{array}$ & 237 & 9.83 & 11 \\
\hline
\end{tabular}




\begin{tabular}{|c|c|c|c|c|}
\hline Rank & Paper & $\begin{array}{l}\text { Total } \\
\text { Citations }\end{array}$ & $\begin{array}{l}\text { Citations/ } \\
\text { Year: Publi- } \\
\text { cation Until } \\
2013\end{array}$ & $\begin{array}{l}\text { Citations } \\
2014\end{array}$ \\
\hline 44 & $\begin{array}{l}\text { Nurick S. Natural-history and results of surgical treatment of spinal-cord } \\
\text { disorder associated with cervical spondylosis. Brain 1972;95:101-\&. }\end{array}$ & 227 & 5.41 & 5 \\
\hline 45 & $\begin{array}{l}\text { Hurwitz EL, Aker PD, Adams AH, et al. Manipulation and mobilization of the } \\
\text { cervical spine-A systematic review of the literature. Spine 1996;21:1746-59. }\end{array}$ & 226 & 13.18 & 2 \\
\hline 46 & $\begin{array}{l}\text { Scholten-Peeters GGM, Verhagen AP, Bekkering GE, et al. Prognostic factors } \\
\text { of whiplash-associated disorders: A systematic review of prospective cohort } \\
\text { studies. Pain 2003;104:303-22. }\end{array}$ & 224 & 21.90 & 5 \\
\hline 47 & $\begin{array}{l}\text { Radanov BP, Sturzenegger M, Distefano G. Long-term outcome after whiplash } \\
\text { injury-a two-year follow-up considering features of injury mechanism and } \\
\text { somatic, radiologic, and psychosocial findings. Medicine 1995;74:281-97. }\end{array}$ & 223 & 12.17 & 4 \\
\hline 48 & $\begin{array}{l}\text { Hogg-Johnson S, van der Velde G, Carroll LJ, et al. The burden and } \\
\text { determinants of neck pain in the general population-Results of the bone } \\
\text { and joint decade 2000-2010 task force on neck pain and its associated } \\
\text { disorders. Spine 2008;33:S39-S51. }\end{array}$ & 222 & 38.00 & 32 \\
\hline 49 & $\begin{array}{l}\text { Wright NM, Lauryssen C. Vertebral artery injury in C1-2 transarticular screw } \\
\text { fixation: Results of a survey of the American Association of Neurological } \\
\text { Surgeons/Congress of Neurological Surgeons section on disorders of the } \\
\text { spine and peripheral nerves. Journal of Neurosurgery 1998;88:634-40. }\end{array}$ & 221 & 13.73 & 15 \\
\hline 50 & $\begin{array}{l}\text { Borghouts JAJ, Koes BW, Bouter LM. The clinical course and prognostic } \\
\text { factors of non-specific neck pain: a systematic review. Pain 1998;77:1-13. }\end{array}$ & 220 & 14.13 & 8 \\
\hline 51 & $\begin{array}{l}\text { Lunsford LD, Bissonette DJ, Jannetta PJ, et al. Anterior surgery for cervical disk } \\
\text { disease .1. Treatment of lateral cervical disk herniation in } 253 \text { cases. } \\
\text { Journal of Neurosurgery 1980;53:1-11. }\end{array}$ & 219 & 6.42 & 7 \\
\hline 52 & $\begin{array}{l}\text { Grob D, Crisco JJ, Panjabi MM, et al. Biomechanical evaluation of four } \\
\text { different posterior atlantoaxial fixation techniques. Spine 1992;17:480-90. }\end{array}$ & 218 & 9.95 & 9 \\
\hline 53 & $\begin{array}{l}\text { Gore DR, Sepic SB, Gardner GM. Roentgenographic findings of the cervical- } \\
\text { spine in asymptomatic people. Spine 1986;11:521-4. }\end{array}$ & 218 & 7.56 & 14 \\
\hline 54 & $\begin{array}{l}\text { Jull G, Trott P, Potter H, et al. A randomized controlled trial of exercise and } \\
\text { manipulative therapy for cervicogenic headache. Spine 2002;27:1835-43. }\end{array}$ & 216 & 18.18 & 16 \\
\hline 55 & $\begin{array}{c}\text { Ariens GA, van Mechelen W, Bongers PM, et al. Physical risk factors for neck } \\
\text { pain. Scandinavian Journal of Work Environment \& Health 2000;26:7-19. } \\
\end{array}$ & 214 & 15.23 & 16 \\
\hline 56 & $\begin{array}{l}\text { Radhakrishnan K, Litchy WJ, Ofallon WM, et al. Epidemiology of cervical } \\
\text { radiculopathy - a population-based study from Rochester, Minnesota, } 1976 \\
\text { through 1990. Brain 1994;117:325-35. }\end{array}$ & 213 & 9.79 & 27 \\
\hline 57 & $\begin{array}{l}\text { Jeanneret B, Magerl F. Primary posterior fusion C } 1 / 2 \text { in odontoid fractures- } \\
\text { indications, technique, and results of transarticular screw fixation. Journal } \\
\text { of Spinal Disorders 1992;5:464-75. }\end{array}$ & 212 & 9.57 & 11 \\
\hline 58 & $\begin{array}{l}\text { Sterling M, Jull G, Vicenzino B, et al. Sensory hypersensitivity occurs soon } \\
\text { after whiplash injury and is associated with poor recovery. Pain } \\
2003 ; 104: 509-17 \text {. }\end{array}$ & 211 & 19.30 & 18 \\
\hline 59 & $\begin{array}{l}\text { Grob D, Jeanneret B, Aebi M, et al. Atlantoaxial fusion with transarticular } \\
\text { screw fixation. Journal of Bone and Joint Surgery-British Volume } \\
\text { 1991;73:972-6. }\end{array}$ & 209 & 9.14 & 8 \\
\hline 60 & $\begin{array}{l}\text { Paramore CG, Dickman CA, Sonntag VKH. The anatomical suitability of the } \\
\text { C1-2 complex for transarticular screw fixation. Journal of Neurosurgery } \\
\text { 1996;85:221-4. }\end{array}$ & 207 & 11.18 & 17 \\
\hline 61 & $\begin{array}{l}\text { Davis JW, Phreaner DL, Hoyt DB, et al. The etiology of missed cervical-spine } \\
\text { injuries. Journal of Trauma-Injury Infection and Critical Care 1993;34:342-6. } \\
\end{array}$ & 206 & 10.05 & 5 \\
\hline 62 & $\begin{array}{l}\text { Panjabi MM, Duranceau J, Goel V, et al. Cervical human vertebrae - } \\
\text { quantitative 3-dimensional anatomy of the middle and lower regions. Spine } \\
\text { 1991;16:861-9. }\end{array}$ & 206 & 8.73 & 14 \\
\hline 63 & $\begin{array}{l}\text { Baba H, Furusawa N, Imura S, et al. Late radiographic findings after anterior } \\
\text { cervical fusion for spondylotic myeloradiculopathy. Spine 1993;18:2167-73. }\end{array}$ & 205 & 9.40 & 17 \\
\hline 64 & $\begin{array}{l}\text { Penning L. Normal movements of cervical-spine. American Journal of } \\
\text { Roentgenology 1978;130:317-26. }\end{array}$ & 205 & 5.57 & 10 \\
\hline 65 & $\begin{array}{l}\text { Conlon PW, Isdale IC, Rose BS. Rheumatoid arthritis of cervical spine-an } \\
\text { analysis of } 333 \text { cases. Annals of the Rheumatic Diseases } 1966 ; 25: 120-\& \text {. }\end{array}$ & 205 & 4.30 & 3 \\
\hline
\end{tabular}




\section{TABLE 2 (Continued)}

\begin{tabular}{|c|c|c|c|c|}
\hline Rank & Paper & $\begin{array}{l}\text { Total } \\
\text { Citations }\end{array}$ & $\begin{array}{c}\text { Citations/ } \\
\text { Year: Publi- } \\
\text { cation Until } \\
2013\end{array}$ & $\begin{array}{l}\text { Citations } \\
2014\end{array}$ \\
\hline 66 & $\begin{array}{l}\text { Sjaastad O, Fredriksen TA, Pfaffenrath V. Cervicogenic headache-diagnostic- } \\
\text { criteria. Headache 1990;30:725-6. }\end{array}$ & 200 & 8.43 & 6 \\
\hline 67 & $\begin{array}{l}\text { Teresi LM, Lufkin RB, Reicher MA, et al. Asymptomatic degenerative disk } \\
\text { disease and spondylosis of the cervical-spine-MR imaging. Radiology } \\
\text { 1987;164:83-8. }\end{array}$ & 199 & 7.35 & 8 \\
\hline 68 & $\begin{array}{l}\text { Ylinen J, Takala EP, Nykanen M, et al. Active neck muscle training in the } \\
\text { treatment of chronic neck pain in women-A randomized controlled trial. } \\
\text { Jama-Journal of the American Medical Association 2003;289:2509-16. }\end{array}$ & 198 & 17.80 & 20 \\
\hline 69 & $\begin{array}{l}\text { Fang HSY, Ong GB. Direct anterior approach to the upper cervical spine. } \\
\text { Journal of Bone and Joint Surgery-American Volume 1962;44:1588-604. }\end{array}$ & 197 & 3.82 & 2 \\
\hline 70 & $\begin{array}{l}\text { Jones EL, Heller JG, Silcox DH, et al. Cervical pedicle screws versus lateral } \\
\text { mass screws-Anatomic feasibility and biomechanical comparison. Spine } \\
\text { 1997;22:977-82. }\end{array}$ & 194 & 11.25 & 14 \\
\hline 71 & $\begin{array}{l}\text { Norris SH, Watt I. The prognosis of neck injuries resulting from rear-end } \\
\text { vehicle collisions. Journal of Bone and Joint Surgery-British Volume } \\
\text { 1983;65:608-11. }\end{array}$ & 192 & 6.40 & 0 \\
\hline 72 & $\begin{array}{l}\text { Youdas JW, Carey JR, Garrett TR. Reliability of measurements of cervical- } \\
\text { spine range of motion-comparison of three methods. Physical Therapy } \\
1991 ; 71: 98-104 .\end{array}$ & 191 & 8.14 & 12 \\
\hline 73 & $\begin{array}{l}\text { Dickman CA, Sonntag VKH. Posterior C1-C2 transarticular screw fixation for } \\
\text { atlantoaxial arthrodesis. Neurosurgery } 1998 ; 43: 275-80 \text {. }\end{array}$ & 189 & 11.87 & 11 \\
\hline 74 & $\begin{array}{l}\text { Caspar W, Barbier DD, Klara PM. Anterior cervical fusion and Caspar plate } \\
\text { stabilization for cervical trauma. Neurosurgery 1989;25:491-502. }\end{array}$ & 189 & 7.63 & 6 \\
\hline 75 & $\begin{array}{l}\text { Rogers WA. Fractures and dislocations of the cervical spine; an end-result } \\
\text { study. The Journal of bone and joint surgery. American volume 1957;39- } \\
\text { A:341-76. }\end{array}$ & 189 & 3.36 & 1 \\
\hline 76 & $\begin{array}{l}\text { Buskila D, Neumann L, Vaisberg G, et al. Increased rates of fibromyalgia } \\
\text { following cervical spine injury-A controlled study of } 161 \text { cases of } \\
\text { traumatic injury. Arthritis and Rheumatism 1997;40:446-52. }\end{array}$ & 188 & 11.38 & 6 \\
\hline 77 & $\begin{array}{l}\text { Mair WGP, Druckman R. The pathology of spinal cord lesions and their } \\
\text { relation to the clinical features in protrusion of cervical intervertebral discs. } \\
\text { Brain 1953;76:70-91. }\end{array}$ & 188 & 3.10 & 2 \\
\hline 78 & $\begin{array}{l}\text { Flanders AE, Schaefer DM, Doan HT, et al. Acute cervical-spine trauma - } \\
\text { correlation of MR imaging findings with degree of neurologic deficit. } \\
\text { Radiology } 1990 ; 177: 25-33 \text {. }\end{array}$ & 187 & 7.91 & 5 \\
\hline 79 & $\begin{array}{l}\text { Dwyer A, Aprill C, Bogduk N. Cervical zygapophyseal joint pain patterns .1. } \\
\text { A study in normal volunteers. Spine 1990;15:453-7. }\end{array}$ & 187 & 7.65 & 11 \\
\hline 80 & $\begin{array}{l}\text { Menezes } \mathrm{AH}, \text { Vangilder JC. Transoral-transpharyngeal approach to the } \\
\text { anterior craniocervical junction-10-year experience with } 72 \text { patients. } \\
\text { Journal of Neurosurgery 1988;69:895-903. }\end{array}$ & 187 & 7.16 & 8 \\
\hline 81 & $\begin{array}{l}\text { Fielding JW, Vancochran G, Lawsing JF, et al. Tears of transverse ligament of } \\
\text { atlas-clinical and biomechanical study. Journal of Bone and Joint Surgery- } \\
\text { American Volume 1974;A 56:1683-91. }\end{array}$ & 187 & 4.72 & 3 \\
\hline 82 & $\begin{array}{l}\text { Emery SE, Bohlman HH, Bolesta MJ, et al. Anterior cervical decompression } \\
\text { and arthrodesis for the treatment of cervical spondylotic myelopathy-Two } \\
\text { to } 17 \text {-year follow-up. Journal of Bone and Joint Surgery-American Volume } \\
1998 ; 80 \mathrm{~A}: 941-51 \text {. }\end{array}$ & 186 & 11.53 & 13 \\
\hline 83 & $\begin{array}{l}\text { Cattell HS, Filtzer DL. Pseudosubluxation and other normal variations in } \\
\text { cervical spine in children. A study of } 160 \text { children. Journal of Bone and } \\
\text { Joint Surgery-American Volume 1965;A 47:1295-\&. }\end{array}$ & 186 & 3.83 & 2 \\
\hline 84 & $\begin{array}{l}\text { Wolf BS, Khilnani M, Malis L. The sagittal diameter of the bony cervical } \\
\text { spinal canal and its significance in cervical spondylosis. Jour Mt Sinai Hosp } \\
1956 ; 23: 283-92 \text {. }\end{array}$ & 186 & 3.21 & 3 \\
\hline 85 & $\begin{array}{l}\text { Sharp J, Purser DW. Spontaneous atlanto-axial dislocation in ankylosing } \\
\text { spondylitis and rheumatoid arthritis. Annals of the rheumatic diseases } \\
1961 ; 20: 47-77 \text {. }\end{array}$ & 185 & 3.54 & 1 \\
\hline
\end{tabular}




\begin{tabular}{|c|c|c|c|c|}
\hline Rank & Paper & $\begin{array}{l}\text { Total } \\
\text { Citations }\end{array}$ & $\begin{array}{l}\text { Citations/ } \\
\text { Year: Publi- } \\
\text { cation Until } \\
2013\end{array}$ & $\begin{array}{l}\text { Citations } \\
2014\end{array}$ \\
\hline 86 & $\begin{array}{l}\text { Obelieniene D, Schrader } \mathrm{H} \text {, Bovim G, et al. Pain after whiplash: a prospective } \\
\text { controlled inception cohort study. Journal of Neurology Neurosurgery and } \\
\text { Psychiatry 1999;66:279-83. }\end{array}$ & 184 & 12.79 & 5 \\
\hline 87 & $\begin{array}{l}\text { Ariens GAM, van Mechelen W, Bongers PM, et al. Psychosocial risk factors } \\
\text { for neck pain: A systematic review. American Journal of Industrial Medicine } \\
\text { 2001;39:180-93. }\end{array}$ & 183 & 14.33 & 11 \\
\hline 88 & $\begin{array}{l}\text { Goel A, Desai KI, Muzumdar DP. Atlantoaxial fixation using, plate and screw } \\
\text { method: A report of } 160 \text { treated patients. Neurosurgery 2002;51:1351-6. }\end{array}$ & 182 & 15.00 & 17 \\
\hline 89 & $\begin{array}{l}\text { Lees F, Turner JW. Natural history and prognosis of cervical spondylosis. } \\
\text { British medical journal 1963;2:1607-10. }\end{array}$ & 182 & 3.62 & 1 \\
\hline 90 & $\begin{array}{l}\text { Stiell IG, Clement CM, McKnight RD, et al. The Canadian C-spine rule versus } \\
\text { the NEXUS low-risk criteria in patients with trauma. New England Journal } \\
\text { of Medicine 2003;349:2510-8. }\end{array}$ & 180 & 15.80 & 22 \\
\hline 91 & $\begin{array}{l}\text { Borghouts JAJ, Koes BW, Vondeling } \mathrm{H} \text {, et al. Cost-of-illness of neck pain in } \\
\text { The Netherlands in 1996. Pain 1999;80:629-36. }\end{array}$ & 180 & 11.86 & 14 \\
\hline 92 & $\begin{array}{l}\text { Henderson CM, Hennessy RG, Shuey HM, et al. Posterior-lateral foraminotomy } \\
\text { as an exclusive operative technique for cervical radiculopathy-a review of } \\
846 \text { consecutively operated cases. Neurosurgery 1983;13:504-12. }\end{array}$ & 180 & 5.70 & 9 \\
\hline 93 & $\begin{array}{l}\text { Sjaastad O, Fredriksen TA, Pfaffenrath V, et al. Cervicogenic headache: } \\
\text { Diagnostic criteria. Headache 1998;38:442-5. }\end{array}$ & 178 & 11.00 & 13 \\
\hline 94 & $\begin{array}{l}\text { Mummaneni PV, Burkus JK, Haid RW, et al. Clinical and radiographic analysis } \\
\text { of cervical disc arthroplasty compared with allograft fusion: a randomized } \\
\text { controlled clinical trial. Journal of Neurosurgery-Spine 2007;6:198-209. }\end{array}$ & 177 & 24.83 & 28 \\
\hline 95 & $\begin{array}{l}\text { Sawin PD, Traynelis VC, Menezes AH. A comparative analysis of fusion rates } \\
\text { and donor-site morbidity for autogeneic rib and iliac crest bone grafts in } \\
\text { posterior cervical fusions. Journal of Neurosurgery 1998;88:255-65. }\end{array}$ & 176 & 11.07 & 10 \\
\hline 96 & $\begin{array}{l}\text { Kotani Y, Cunningham BW, Abumi K, et al. Biomechanical analysis of } \\
\text { cervical stabilization systems - an assessment of transpedicular screw } \\
\text { fixation in the cervical-spine. Spine 1994;19:2529-39. }\end{array}$ & 176 & 8.89 & 7 \\
\hline 97 & $\begin{array}{l}\text { Sheehan S, Bauer RB, Meyer JS. Vertebral artery compression in cervical } \\
\text { spondylosis-arteriographic demonstration during life of vertebral artery } \\
\text { insufficiency due to rotation and extension of the neck. Neurology } \\
\text { 1960;10:968-86. }\end{array}$ & 176 & 3.32 & 0 \\
\hline 98 & $\begin{array}{l}\text { Clark CR, White AA. Fractures of the dens-a multicenter study. Journal of } \\
\text { Bone and Joint Surgery-American Volume 1985;67A:1340-8. }\end{array}$ & 174 & 6.00 & 6 \\
\hline 99 & $\begin{array}{l}\text { Satomi K, Nishu Y, Kohno T, et al. Long-term follow-up-studies of open-door } \\
\text { expansive laminoplasty for cervical stenotic myelopathy. Spine } \\
\text { 1994;19:507-10. }\end{array}$ & 173 & 8.26 & 16 \\
\hline 100 & $\begin{array}{l}\text { Zdeblick TA, Ducker TB. The use of freeze-dried allograft bone for anterior } \\
\text { cervical fusions. Spine 1991;16:726-9. }\end{array}$ & 173 & 7.22 & 7 \\
\hline
\end{tabular}

less often because they are increasingly being incorporated into more recent studies. ${ }^{14}$ This same phenomenon might also account for the fact that most papers originated in the 1990s $(n=42)$ even though, theoretically, older publications have had more time to accumulate a high citation count.

The most cited paper accumulated 879 citations up until the end of 2014 while the $100^{\text {th }}$ placed paper (a 1991 study by Zdeblick and Ducker describing the use of freeze-dried allograft bone for anterior cervical fusions) was cited a total of 173 times (average for all studies: 265 citations). While the top 10 studies spanned a range of 493 citations
(386-879 total citations), the last 10 studies spanned a range of only seven citations (173-180 total citations), thus indicating, that at the bottom there is the most "movement": Here a single citation can decide over an appearance on the top 100 list. It is therefore likely that this study conducted again a few years later will look different, especially the bottom half.

Since during the search process no restriction was placed on the journal selection, a total of 30 different journals were identified. A total of 17 journals published, however, only one paper, while the top three journals (Spine, J Bone Joint Surg Am, and J Neurosurg) published half $(\mathrm{n}=50)$ of all 


\begin{tabular}{|l|c|}
\hline TABLE 3. Journals With Multiple Publications \\
\hline Journal & No. of Papers \\
\hline Spine & 25 \\
\hline J Bone Joint Surg Am & 17 \\
\hline J Neurosurg & 8 \\
\hline Brain & 6 \\
\hline Neurosurgery & 5 \\
\hline Pain & 5 \\
\hline N Engl J Med & 4 \\
\hline JAMA & 3 \\
\hline Ann Rheum Dis & 2 \\
\hline Cell & 2 \\
\hline Headache & 2 \\
\hline J Bone Joint Surg Br & 2 \\
\hline Radiology & 2 \\
\hline Total & 83 \\
\hline
\end{tabular}

studies. A similar pattern for spine research was noted before, ${ }^{10,11}$ indicating the degree of specialization and established leaderships among scientific journals. The top four countries of origin are all English speaking and accounted for a total of 70 studies, with the USA in first position $(\mathrm{n}=48)$.

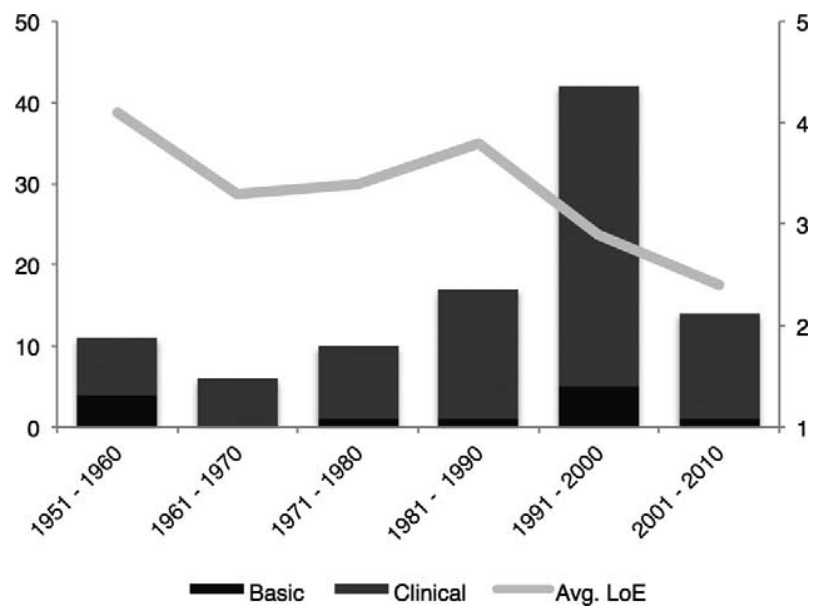

Figure 2. Publications per decade with average level of evidence for clinical studies.

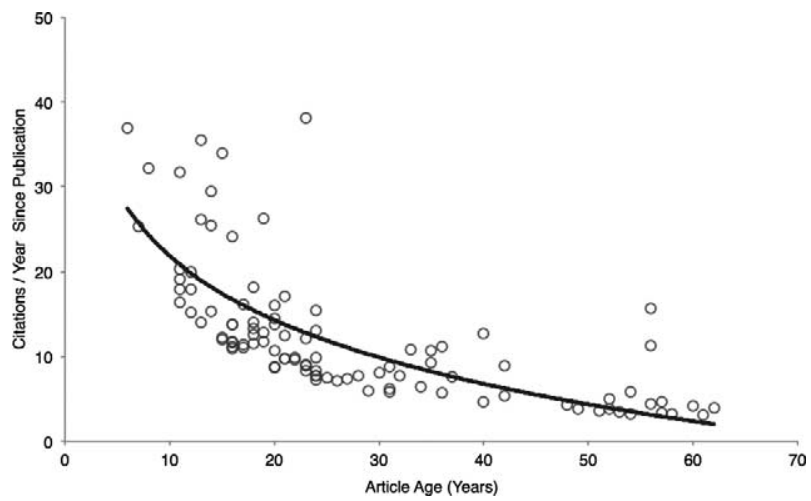

Figure 3. Correlation between article age and average citations per year since publication.

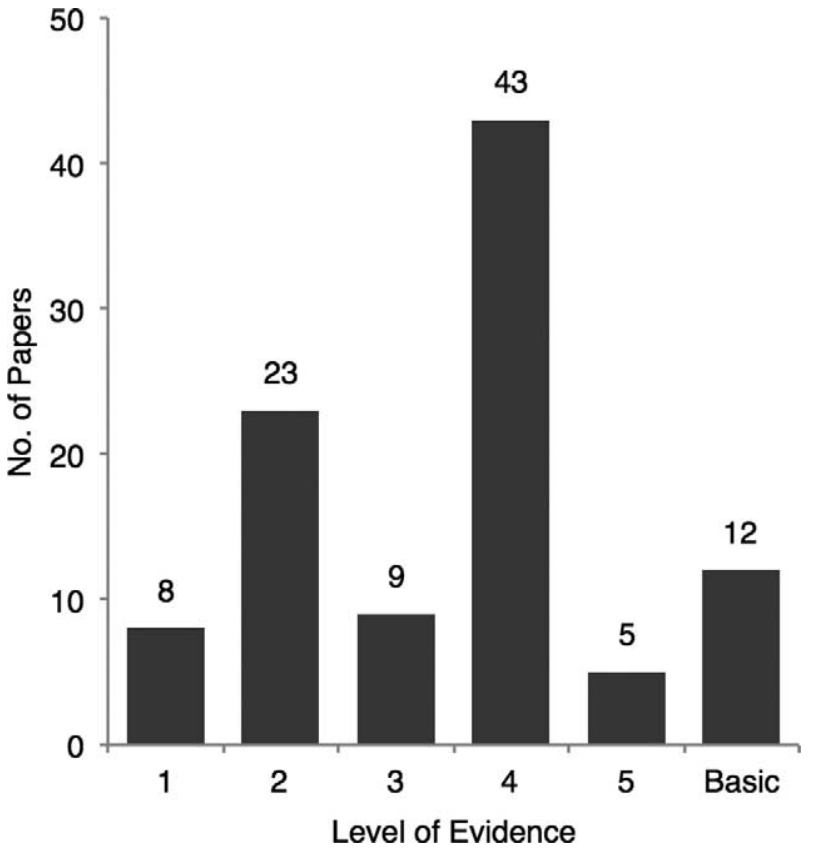

Figure 4. Level of evidence.

As seen in bibliographic studies in different fields, ${ }^{5}$ evidence level 4 was the most common in this study as well with 43 papers. Only eight studies were deemed to be of level 1 by the research team. Many papers on the top 100 list provide something novel, most commonly a surgical technique and most often with relatively few patients and without a comparison group. It seems likely, that many studies conducted on the same surgical technique at a later point in time cite the classic study introducing the technique into the medical literature, thus elevating its citation count. After some time, the before mentioned phenomenon of "obliteration by incorporation" might, however, gradually offset this effect. While it is tempting to conclude that the level of

\begin{tabular}{|l|c|l|c|}
\hline \multicolumn{4}{|c|}{ TABLE 4. First and Senior Authors With } \\
Multiple Publications
\end{tabular}




\begin{tabular}{|l|c|}
\hline \multicolumn{2}{|l|}{ TABLE 5. Type of Paper } \\
\hline Type of Paper & No. of Papers \\
\hline Surgical technique & 30 \\
\hline Clinical outcomes & 11 \\
\hline Anatomy & 10 \\
\hline Natural history & 10 \\
\hline Epidemiology & 10 \\
\hline Clinical description & 9 \\
\hline Classification & 5 \\
\hline Conservative therapy & 4 \\
\hline Clinical guidelines & 3 \\
\hline Imaging & 3 \\
\hline Genetics & 2 \\
\hline Questionnaire development & 1 \\
\hline Physical examination Technique & 1 \\
\hline Pathogenesis & 1 \\
\hline Total & 100 \\
\hline
\end{tabular}

evidence is not a criterion for publication success (as measured in the number of citations), this might not be true as there is a tendency towards a better level of evidence as time progresses (Figure 2). While for studies from the 1950s level of evidence averaged to 4.1, in the last decade (20012010 ) it went down to 2.4. A possible explanation might be that in earlier times a lot of studies introduced "a first", while more recently more research has been conducted on the evaluation about previously made assumptions, requiring a much stronger statistical power and therefore a lower level of evidence. The decrease in level of evidence seen over time in this study is, however, not unique and might as well be due to a general tendency in the medical literature towards a better level of evidence. ${ }^{15}$

Because no restriction was placed on the field of study, basic research papers $(n=12)$ appeared alongside with clinical studies $(\mathrm{n}=88)$. While approximately half $(\mathrm{n}=5)$ of the basic research was conducted on the anatomy of the cervical spine, two studies also came from the field of genetics demonstrating the effect the expression of two genes (Hox-1.1 and Hoxb-4) have on the development of cervical vertebrae in mice. Both studies (ranked $22^{\text {nd }}$ and $\left.31^{\text {st }}\right)$ were published in the 90 s and both have, despite their relatively young age, below average citations in 2014 (one time and three times, respectively). It has been noted before that basic research tends to get cited faster but not more often than clinical research. ${ }^{5}$

"Degenerative" is the most common type with 41 studies, followed by Trauma $(n=28)$. A total of 11 papers within the latter category dealt with some aspect of whiplash injury, possibly reflecting the medical and political controversies this disease entity has been attracting. Only few studies fell into the categories "Rheumatology" $(\mathrm{n}=3)$ and "Oncology" $(\mathrm{n}=1)$. The 2012 bibliometric study on the entire spine also listed a table with the number of articles by subspecialty. The distribution of studies was very similar, showing that the research focus for the cervical

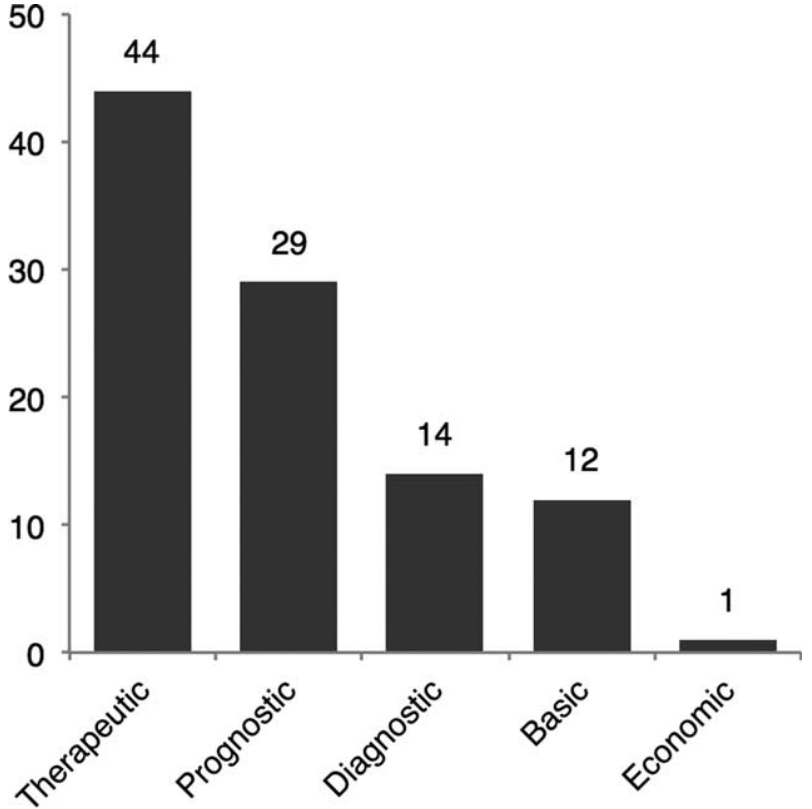

Figure 5. Study type.

spine is in general not much different from the entire spine. ${ }^{10}$

Even though citation analysis has its limitations, ${ }^{16,17}$ it is the current de facto gold standard for measuring the impact of scientific literature.

It is important to note that citation analysis can reflect the situation of only one point in time. Every day new publications appear citing previous papers. Thus, a citation analysis is as dynamic as the analyzed research field as a whole. Important progress is made constantly and a bibliographic study will most likely look different already months later.

The chosen two-step approach to identify eligibly publications demonstrates the impact a widening of search terms can have: A total of 27 additional studies were identified, including the first ranking one. This improvement in comprehensiveness came, however, at the cost of a drastically decreased hit rate (studies meeting all inclusion criteria per studies manually sorted) from 0.24 with the initial four keywords down to 0.01 with 38 keywords. Even though this approach therefore consumes more of the research team's resources, because of the much higher likelihood to identify all publications relevant to the investigation, we believe it to be a valid approach and recommend it to be considered for future bibliometric studies. Often, the lack of higher-level keywords in published research prevents it from getting identified by the obvious search terms. For example, one study in our list had no keywords pointing to the spine. The sole indicator for it being a cervical spine study was the term "atlantoaxial" in the title. This demonstrates the importance of the attempt to foresee as many relevant titles as possible. As our experience goes, even in a rather narrow field such as the cervical spine it can, however, prove difficult to identify all the required terms. A preliminary search to identify keywords can help in such a situation. 
Unfortunately, no matter what the approach chosen, it is impossible to know whether every eligible study really has been identified without manually sorting every paper ever published. With the two-step approach chosen, we however believe it to be at least highly likely that the "true" list of the 100 most cited cervical spine publications would not look much different than the list published here.

\section{Key Points}

The most cited article identified with a total of 879 citations was the publication in I Neurosurg from 1958 by the single author Cloward describing the anterior approach for the removal of ruptured cervical discs.

- Second placed with a total citation count of 877 was the publication from 1991 by Vernon and Mior creating the Neck Disability Index by modification of the established Oswestry Low Back Pain Index.

口 The third most cited paper was the 1958 published study by Smith and Robinson, also describing the anterior approach for the removal of intervertebral discs and interbody fusion.

- Most papers either fell into the subspecialty of degeneration $(n=41)$ or trauma $(n=28)$ and were most commonly published in the $1990 \mathrm{~s}(\mathrm{n}=42)$.

Most studies were published in Spine $(n=25)$ and originated in the USA $(n=48)$.

\section{References}

1. Garfield E. Citation analysis as a tool in journal evaluation journals can be ranked by frequency and impact of citations for science policy studies. Science 1972;178:471-9.
2. Heller AR, Lepore M, Bhangu A, et al. Citation classics in surgery: an analysis of the 100 most cited academic articles in surgical journals. Br J Surg 2015;102:59.

3. Lefaivre KA, Shadgan B, O’Brien PJ. 100 most cited articles in orthopaedic surgery. Clin Orthop Relat Res 2011;469: 1487-97.

4. Tas F. An analysis of the most-cited research papers on oncology: which journals have they been published in?. Tumor Biol 2014;35:4645-9.

5. Ahmad SS, Evangelopoulos DS, Abbasian M, et al. The hundred most-cited publications in orthopaedic knee research.J Bone Joint Surg 2014;96:e190.

6. Cassar-Gheiti AJ, Downey RE, Byrne DP, et al. The 25 most cited articles in arthroscopic orthopaedic surgery. Arthroscopy 2012;28:548-64.

7. Jia ZW, Ding F, Wu YH, et al. The 50 most-cited articles in orthopaedic surgery from Mainland China. Clin Orthop Relat Res 2015;473:2423-30.

8. Gurbuz Y, Sugun TS, Ozaksar K. A bibliometric analysis of orthopedic publications originating from Turkey. Acta Orthop Traumato 2015;49:57-66.

9. Cao F, Li J, Li A, et al. Citation classics in acute pancreatitis. Pancreatology 2012;12:325-30.

10. Murray MR, Wang TY, Schroeder GD, et al. The 100 most cited spine articles. Eur Spine J 2012;21:2059-69.

11. Steinberger J, Skovrlj B, Caridi JM, et al. The top 100 classic papers in lumbar spine surgery. Spine (Phila Pa 1976) 2015;40: 740-7.

12. Bhandari M, Swiontkowski MF, Einhorn TA, et al. Interobserver agreement in the application of levels of evidence to scientific papers in the American volume of the Journal of Bone and Joint Surgery. J Bone Joint Surg Am 2004;86-A:1717-20.

13. Fairbank JC, Pynsent PB. The Oswestry Disability Index. Spine (Phila Pa 1976) 2000;25:2940-52; discussion 52.

14. Garfield E. 100 citation-classics from the Journal-of-the-American-Medical-Association. JAMA 1987;257:52-9.

15. Grant HM, Tjoumakaris FP, Maltenfort MG, et al. Levels of evidence in the clinical sports medicine literature: are we getting better over time?. Am J Sports Med 2014;42:1738-42.

16. Boudoulas H. Essays on citation classics in cardiology. Cardiology 2014;127:263-4.

17. Ioannidis JPA, Boyack KW, Small H, et al. Bibliometrics: is your most cited work your best?. Nature 2014;514:561-2. 